\title{
A Study on Isolation of Acid and Bile Tolerance on lactic acid bacteria (LAB) in dairy product (Dahi) of Bengaluru in Karnataka
}

\author{
Madhusudan, N.M ${ }^{1}$, Manjunath. $\mathrm{H}^{2}$, Dhavalagi.Pallavi ${ }^{3}$ \\ Dairy Science College, Mahagaon Cross, Kalburgi-585316, Karnataka
}

\begin{abstract}
Fermented milk products possess very important input and also plays a vital role in providing nutritional and therapeutic properties especially in dairy industries. Dahi is an indigenous and common fermented milk product of household and also has its own commercial value, prepared using lactic culture with probiotic properties. The present study was undertaken to find out the presence of acid and bile tolerance cultures for dahi samples collected from Bangalore market area. This process was carried to obtain the probiotic culture which is very much significant in the present scenario of any food and nutritional aspects of any industry related to food business. Further, the primary data were collected from different BBMP zones of Bengaluru consisting of 24 numbers of dahi samples were used for the study purpose. The results revealed that, the presence of lactococci, streptococci, leuconsotoc and lactobacilli were the major lactic acid bacterial growth. Among 82 lactic isolates, 43 isolates showed better activity in milk, acidity and DMC. Further the isolates sceening for acid and bile tolerance by adjusting the $\mathrm{pH}$ of the medium to 2.0 and by using $0.3 \%$ oxbile. The maximum acid and bile tolerated isolates 12 numbers were genotypically identified as L.lactis ssp. Lactis (1) and L.lactis ssp. Lactis bv diacetylactis(1), among the 3 lactobacilli isolates L.plantarum (1), L.fermnetum (1) and L.helviticus (1) in case of leuconostocs isolates as L. mesentroides ssp. mesentroides (2) and all the streptococci as S.thermophilus (5). The purpose study is to identify the acid and bile tolerance on lactic acid bacteria and also information on identifying appropriate genotypically species of LAB which are acid and bile tolerant in nature and also boost the dairy industry in long run with these unique qualities which are very much essential for assessing the probiotic nature of particular organisms used in fermented products.
\end{abstract}

\section{Introduction}

The significance of live micro-organisms are investigated across the world which is known for diet, not only for human beings but also animals which acts as an effective barrier for microbial infection (Oh and jung, 2015). In addition many international organization have identified significance of probiotics as a part of health benefits. According to FAO/WHO Probiotics are defined as living organisms which are administrated in adequate amounts confers health benefits on the host (FAO/WHO, 2001). Further many studies such as salminen et al., 1998, Stiler and Holzafel 1977 and Saarela et al., 2002. Reveals that most of the probiotic microorganisms belongs to lactic acid bacteria group, which plays a vital role in maintaining the intestinal ecosystem and also stimulates the immune system of the host (Collin and Gibson 1999). The probiotics are technically suitable for industrial inputs which are non-pathogenic in nature, which also have acid and bile tolerance which can produce sufficient antimicrobial substances for any required culture (Mojgani et al., 2015). Probiotics are smartly recognized as safe microorganisms because of their longitivity and safe which can be used as starter culture in any fermented milk products in dairy industry (EL- Soda et al., 2003, Angmo,k., Kumari A and Bhalla T C., 2016). Probiotics has dynamic role in food industry especially to reduce the risk factors associated with heart disease and resulted in a dose dependent reduction in symptoms of irritable bowel hydrolase of probiotic bacteria helps in decreasing the level of serum cholesterol (Mirenadi et al., 2014). The effect of probiotics in co-agulation of milk causing lactic acid of streptococcus and others due to resonal difference (Bourlioux and Pochart 1988). Presently greater part of dairy industry is dominated by healthy products which are aimed to balance and activity of intestinal micro-flora which are only possible through probiotics especially LAB. In addition selection of lactobacilli as a potential health enhancing probiotic isolates which are extensively used in food and pharmaceutical preparation which directly depends on antibiotic and bile tolerance and also inhibiting the growth of other micro-organisms and secretion of gastric juice which allows probiotics to be established in the intestinal tract therefore the present study was focused with an objective of identifying acid and bile tolerance isolates. 


\section{Materials And Methods}

Dahi samples: Different market brands of dahi samples were collected from eight different Bruhath Bengaluru Mahanagara Paalike (BBMP) zones approximately $100 \mathrm{~g}$ were collected aseptically in sterile sample bottles.

Plating of samples: The dahi samples collected were serially diluted in sterile phosphate buffer. Dilution of first was prepared by transferring $11 \mathrm{~g}$ of dahi to $99 \mathrm{ml}$ of sterile phosphate buffer and mixed thoroughly. Using the first dilution, required dilutions were prepared for lactococci, leuconostoc and lactobacilli. For streptococci, the first dilution was subjected to laboratory pasteurization of $63^{\circ} \mathrm{C}$ for $30 \mathrm{~min}$., cooled to room temperature immediately and separately diluted for required dilutions. The required dilutions of $1 \mathrm{ml}$ were transferred to labeled sterile petri plates poured with, $10-15 \mathrm{ml}$ of molten agar medium maintained at $50^{\circ} \mathrm{C}$ water bath. Two medias were used for the study, viz M17 agar and MRS (De man rogosa sharpe) agar to estimate the parameters such as lactococci $\left(30^{\circ} \mathrm{C} / 24-48\right.$ hours) streptococci $\left(37^{\circ} \mathrm{C} / 24-48\right.$ hours $)$ and leuconostoc $\left(30^{\circ} \mathrm{C} / 24-48\right.$ hours $)$ lactobacilli $\left(37^{\circ} \mathrm{C} / 24-48\right.$ hours) respectively, mixed gently allowed to solidify and anaerobically incubated invertedly in a candle jar. The colonies were counted by selecting the countable plates and average count was expressed as cfu per g. After enumeration, colonies were selected based on the morphology and transferred as well as maintained in respective broth media. After purification, lactic isolates were individually inoculated into sterile skim milk and incubated, time taken for setting was noted and also tested for Titratable acidity (TA) and Direct Microscopic Count (DMC). Acid and bile tolerance tests were carried out as per Rajashekar et al., (2013), while genotypic identification analyzed from an external source such as Macrogen.

\section{Results And Discussion}

Market dahi samples of $100 \mathrm{~g}$ were collected aseptically at low temperature from different BBMP zones of the Bengaluru like Bengaluru East, Bengaluru south, Bengaluru West, Bommanahalli, Dasarahalli, Mahadevapura, Rajarajeshwarinagar and Yelahanka and bought to the laboratory for the analysis of lactic acid bacteria. The average counts of lactococci $4.89 \log _{10} \mathrm{cfu} / \mathrm{g}$, streptococci of $4.48 \log _{10} \mathrm{cfu} / \mathrm{g}$; Leuconostoc of 3.82 $\log _{10} \mathrm{cfu} / \mathrm{g}$ and lactobacilliof $4.98 \log _{10} \mathrm{cfu} / \mathrm{g}$, were obtained in 24 dahi samples on M17 and MRS at $30^{\circ} \mathrm{C}$ and $37^{\circ} \mathrm{C}$ depending on type of lactic acid bacteria. A total number of $82 \mathrm{LAB}$ isolates were obtained from 24 dahi samples. out of which 24 lactic isolates belonged to lactococci (LL1 to LL24); 15 belonged to streptococci (ST1 to ST 15); 10 lactic isolates belongs (LE1 to LE10) and33 belonged to lactobacilli (LB1 to LB33).

LAB isolates ( 82 no's) obtained from the market dahi samples screened for the milk setting, acidity and DMC. Lactococci isolates (8) set milk at $9 \mathrm{~h}$ with acidity of $0.67 \%$ LA and DMC of 7.28 to $7.34 \log _{10} / \mathrm{g}, 8$ streptococci isolates took $6 \mathrm{~h}$ with TA of $0.67 \% \mathrm{LA}$ and DMC of 7.52 to $7.68 \log _{10} / \mathrm{g}$ counts. Out of 10 leuconostoc isolates only 3 isolates set with $14 \mathrm{~h}$ producing acidity of $0.66 \% \mathrm{LA}$ and DMC 7.59 to $7.71 \log _{10} / \mathrm{g}$. Among 33 isolates of lactobacilli, 8 isolates set the milk at $8 \mathrm{~h}$ with TA of $0.68 \%$ LA and DMC ranged 7.57 to $7.79 \log _{10} / \mathrm{g}$.

\section{Screening for acid and bile tolerance of the lactic acid bacterial isolates obtained from dahi samples}

To assess the acid (Table 1) and bile (Table 2) tolerance of selected isolates, four isolates of lactic were selected such as lactococci, streptococci, leuconostoc and lactobacilli with 14, 13, 5 and 11 number of isolates respectively. Further the study results showed that the isolates which showed less curdling time, acidity and more DMC were selected for acid tolerance test using MRS/M17 broth which was previously adjusted to $\mathrm{pH}$ 2.0. Samples drawn immediately after inoculation and after $2 \mathrm{~h}$ of incubation were plated. The Table 1 reveal that out of 14 lactococcal isolates tested, only 2 isolates LL7\& LL10, tolerate to low pH with a marked reduction in their viable count from 6.87 and $7.05, \log _{10} \mathrm{cfu} / \mathrm{g}$ respectively to 4.86 and $5.26 \log _{10} \mathrm{cfu} / \mathrm{ml}$. In case of streptococci, among of 13 isolates tested only 5 isolates, ST1, ST2, ST3, ST7\& ST14,survived at low pH with a minimum reduction in their viable count which was reduced to $2.89,2.21,1.16,3.32$ and $4.61 \log _{10} \mathrm{cfu} / \mathrm{g}$ from the initial count of 5.75, 4.62, 3.91, 4.62 and $6.81 \log _{10} \mathrm{cfu} / \mathrm{ml}$ respectively. Similarly, 2 leuconostoc isolates LE1 and LE4 reduced from 3.39 to 1.27 and 5.89 to $3.42 \log _{10} \mathrm{cfu} / \mathrm{ml}$ respectively, tolerated low pH out of 5 isolates tested. In contrast the majority of lactobacilli isolates (7 No's out of 11) isolates tested, tolerated low $\mathrm{pH}$ and most tolerated is LB2 followed by LB5 and LB24 with a viable count of 2.93, 2.05 and $1.88 \log _{10} \mathrm{cfu} / \mathrm{ml}$ from the initial count of $5.49,4.84$ and $3.53 \log _{10}$ cfu/g respectively. The results obtained were on par with the agreement with Tannock 2004, the present study also showed that the lactobacilli isolates had highest tolerance to acid followed by steptocooci, lactococci and the least survivability was by leuconostoc isolates. 
Table 1: Acid tolerance of the selected lactic isolates

\begin{tabular}{|c|c|c|c|c|c|c|}
\hline \multirow{2}{*}{ Sl. No. } & \multirow{2}{*}{$\begin{array}{c}\text { Type of lactic } \\
\text { isolates }\end{array}$} & \multirow{2}{*}{$\begin{array}{l}\text { No. of } \\
\text { Isolates }\end{array}$} & \multirow{2}{*}{$\begin{array}{c}\text { Isolate } \\
\text { code }\end{array}$} & \multicolumn{3}{|c|}{ Acid Tolerance } \\
\hline & & & & $\mathbf{0 h}$ & $2 \mathbf{h}$ & $\mathrm{CD}(\mathrm{P}<0.05)$ \\
\hline \multirow{14}{*}{1} & \multirow{14}{*}{ Lactococcus } & \multirow{14}{*}{14} & LL1 & $4.27^{\mathrm{a}}$ & $1.46^{\mathrm{b}}$ & 0.37 \\
\hline & & & LL4 & $3.30^{\mathrm{a}}$ & $2.31^{\mathrm{b}}$ & 0.34 \\
\hline & & & LL6 & 2.72 & 0 & 0.16 \\
\hline & & & LL7 & $6.87^{\mathrm{a}}$ & $4.86^{\mathrm{b}}$ & 0.18 \\
\hline & & & LL8 & $4.01^{\mathrm{a}}$ & $1.51^{\mathrm{b}}$ & 0.34 \\
\hline & & & LL9 & $3.36^{\mathrm{a}}$ & $1.41^{\mathrm{b}}$ & 0.34 \\
\hline & & & LL10 & $7.05^{\mathrm{a}}$ & $5.26^{b}$ & 0.33 \\
\hline & & & LL11 & $3.39^{\mathrm{a}}$ & $1.52^{\mathrm{b}}$ & 0.29 \\
\hline & & & LL12 & $2.41^{\mathrm{a}}$ & $1.27^{\mathrm{b}}$ & 0.34 \\
\hline & & & LL15 & $3.80^{\mathrm{a}}$ & $1.52^{\mathrm{b}}$ & 0.21 \\
\hline & & & LL17 & $4.43^{\mathrm{a}}$ & $2.50^{\mathrm{b}}$ & 0.22 \\
\hline & & & LL18 & $4.32^{\mathrm{a}}$ & $1.81^{\mathrm{b}}$ & 0.47 \\
\hline & & & LL19 & $3.47^{\mathrm{a}}$ & $1.51^{\mathrm{b}}$ & 0.18 \\
\hline & & & LL21 & $3.13^{\mathrm{a}}$ & $1.28^{\mathrm{b}}$ & 0.76 \\
\hline \multirow{13}{*}{2} & \multirow{13}{*}{ Streptococcus } & \multirow{13}{*}{13} & ST1 & $5.75^{\mathrm{a}}$ & $2.89^{\mathrm{b}}$ & 0.71 \\
\hline & & & ST2 & $4.62^{\mathrm{a}}$ & $2.21^{\mathrm{b}}$ & 0.32 \\
\hline & & & ST3 & $3.91^{\mathrm{a}}$ & $1.16^{\mathrm{b}}$ & 0.39 \\
\hline & & & ST4 & $3.27^{\mathrm{a}}$ & $1.58^{\mathrm{b}}$ & 0.32 \\
\hline & & & ST5 & $3.51^{\mathrm{a}}$ & $1.61^{b}$ & 0.39 \\
\hline & & & ST6 & $3.42^{\mathrm{a}}$ & $1.28^{\mathrm{b}}$ & 0.20 \\
\hline & & & ST7 & $4.62^{\mathrm{a}}$ & $3.32^{\mathrm{b}}$ & 0.29 \\
\hline & & & ST8 & $3.45^{\mathrm{a}}$ & $1.30^{\mathrm{b}}$ & 0.53 \\
\hline & & & ST9 & 3.30 & NIL & 0.24 \\
\hline & & & ST11 & $3.29^{\mathrm{a}}$ & $1.40^{\mathrm{b}}$ & 0.76 \\
\hline & & & ST12 & $3.08^{\mathrm{a}}$ & $1.13^{b}$ & 0.72 \\
\hline & & & ST14 & $6.81^{\mathrm{a}}$ & $4.6^{\mathrm{b}}$ & 0.52 \\
\hline & & & ST15 & $2.99^{\mathrm{a}}$ & $1.74^{\mathrm{b}}$ & 0.26 \\
\hline \multirow{5}{*}{3} & \multirow{5}{*}{ Leuconostoc } & \multirow{5}{*}{5} & LE1 & $3.39^{\mathrm{a}}$ & $1.27^{\mathrm{b}}$ & 0.64 \\
\hline & & & LE2 & $3.55^{\mathrm{a}}$ & $1.87^{\mathrm{b}}$ & 0.61 \\
\hline & & & LE3 & $3.25^{\mathrm{a}}$ & $1.27^{\mathrm{b}}$ & 0.35 \\
\hline & & & LE4 & $5.89^{\mathrm{a}}$ & $3.42^{b}$ & 0.38 \\
\hline & & & LE5 & $2.97^{\mathrm{a}}$ & $1.37^{b}$ & 0.46 \\
\hline \multirow{11}{*}{4} & \multirow{11}{*}{ Lactobacillus } & \multirow{11}{*}{11} & LB1 & $3.97^{\mathrm{a}}$ & $1.30^{\mathrm{b}}$ & 0.23 \\
\hline & & & LB2 & $5.49^{\mathrm{a}}$ & $2.93^{b}$ & 0.08 \\
\hline & & & LB4 & $3.39^{\mathrm{a}}$ & $1.10^{\mathrm{b}}$ & 0.08 \\
\hline & & & LB5 & $4.84^{\mathrm{a}}$ & $2.05^{\mathrm{b}}$ & 0.52 \\
\hline & & & LB8 & $3.09^{\mathrm{a}}$ & $1.19^{\mathrm{b}}$ & 0.08 \\
\hline & & & LB10 & $4.03^{\mathrm{a}}$ & $1.62^{\mathrm{b}}$ & 0.44 \\
\hline & & & LB11 & $3.13^{\mathrm{a}}$ & $1.46^{\mathrm{b}}$ & 0.28 \\
\hline & & & LB21 & $3.09^{\mathrm{a}}$ & $1.19^{b}$ & 0.42 \\
\hline & & & LB24 & $3.53^{\mathrm{a}}$ & $1.88^{\mathrm{b}}$ & 0.32 \\
\hline & & & LB26 & 2.87 & NIL & 0.08 \\
\hline & & & LB28 & $3.30^{\mathrm{a}}$ & $1.30^{\mathrm{b}}$ & 0.21 \\
\hline
\end{tabular}

Note: Similar superscripts indicate non-significant at the corresponding critical difference

\section{Bile tolerance of lactic acid bacterial isolates}

The bile tolerance of 43 lactic isolates were tested in MRS and M17 broth containing 0.3\% ox bile. After an exposure of $6 \mathrm{~h}$, out of 43 isolates tested only 16 isolates tolerated bile. The Table 2.reveals that among the 14 lactococcal isolates tested, 2 isolates LL7 \&LL10, tolerated to bile with the viable count reducing from the initial 6.81 to $2.93,6.00$ to $4.11 \log _{10} \mathrm{cfu} / \mathrm{ml}$ after $6 \mathrm{~h}$ of exposure. In case of streptococci out of 13 isolates tested only 5 isolates, ST1, ST2, ST3, ST7 \& ST14 tolerated to bile with viable count reduced to 2.62, 2.00, $1.43,3.52 \& 3.39 \log _{10} \mathrm{cfu} / \mathrm{ml}$ from the initial count of 5.22, 5.24, 4.10, 3.94 and $6.18 \log _{10} \mathrm{cfu} / \mathrm{ml}$ respectively. Similarly out of 5 leuconostoc isolates tested only 2 isolates,LE1 and LE4 showed tolerance to bile, in these isolates the viable count reduced from 3.76 and 4.90 to 1.36 and $2.48 \log _{10} \mathrm{cfu} / \mathrm{ml}$ respectively, whereas 11 lactobacilli isolates tested 7 isolates showed tolerance to bile salt. The maximum tolerance was shown by LB2 followed by LB5 and LB24, with viable count of 2.86, 1.86 and 1.46 from the initial count of 5.63, 4.42 and $3.23 \log _{10} \mathrm{cfu} / \mathrm{ml}$ while the lowest tolerance was exhibited by LB4 \& LB26. The significant $(\mathrm{P}<0.05)$ reduction in survival of the strains observed after subjecting Lactococci (LL10), Streptococci (ST14), Leuconostoc (LE4) and Lactobacillus (LB2) to bile tolerance and were less affected during the bile they survived even after $6 \mathrm{~h}$ exposure. Rajashekar et al. (2013) also carried out a similar study to find the probiotic nature of lactic isolates of domestic dahi samples from Bengaluru and found that only S.thermophilus ST3 out of 9 lactic isolates tolerated acid and bile while another study by Mahesh et al. (2016) revaled that out of 15 lactic isolates obtained from the 8 dahi samples from Bengaluru only the L. lactis ssp. lactis LC1, S.thermophilus ST1, Leuconostoc mesentroides ssp. mesentroides LEU1 and L. fermentum LB4 tolerated both acid and bile. 
Table 2: Bile tolerance of the selected lactic isolates

\begin{tabular}{|c|c|c|c|c|c|c|}
\hline \multirow{2}{*}{$\begin{array}{l}\text { Sl. } \\
\text { No. }\end{array}$} & \multirow{2}{*}{$\begin{array}{l}\text { Type of lactic } \\
\text { isolates }\end{array}$} & \multirow{2}{*}{$\begin{array}{c}\text { No. of } \\
\text { Isolates }\end{array}$} & \multirow{2}{*}{$\begin{array}{c}\text { Isolate } \\
\text { code }\end{array}$} & \multicolumn{3}{|c|}{ Bile Tolerance } \\
\hline & & & & Oh & 6h & $\mathrm{CD}(\mathrm{P}<0.05)$ \\
\hline \multirow{14}{*}{1} & \multirow{14}{*}{ Lactococcus } & \multirow{14}{*}{14} & LL1 & $3.52^{\mathrm{a}}$ & $1.46^{\mathrm{b}}$ & 0.32 \\
\hline & & & LL4 & $3.28^{\mathrm{a}}$ & $2.31^{\mathrm{b}}$ & 0.30 \\
\hline & & & LL6 & $2.72^{\mathrm{a}}$ & NIL & 0.12 \\
\hline & & & LL7 & $6.81^{\mathrm{a}}$ & $2.93^{\mathrm{b}}$ & 0.19 \\
\hline & & & LL8 & $4.01^{\mathrm{a}}$ & $1.51^{\mathrm{b}}$ & 0.31 \\
\hline & & & LL9 & $3.22^{\mathrm{a}}$ & $1.08^{b}$ & 0.37 \\
\hline & & & LL10 & $6.00^{\mathrm{a}}$ & $4.11^{b}$ & 0.31 \\
\hline & & & LL11 & $2.52^{\mathrm{a}}$ & $1.11^{\mathrm{b}}$ & 0.27 \\
\hline & & & LL12 & $2.80^{\mathrm{a}}$ & $1.10^{\mathrm{b}}$ & 0.35 \\
\hline & & & LL15 & $3.34^{\mathrm{a}}$ & $1.38^{\mathrm{b}}$ & 0.27 \\
\hline & & & LL17 & $4.93^{\mathrm{a}}$ & $1.41^{\mathrm{b}}$ & 0.22 \\
\hline & & & LL18 & $3.84^{\mathrm{a}}$ & $1.45^{b}$ & 0.49 \\
\hline & & & LL19 & $3.08^{\mathrm{a}}$ & $1.46^{\mathrm{b}}$ & 0.11 \\
\hline & & & LL21 & $3.13^{\mathrm{a}}$ & $1.28^{\mathrm{b}}$ & 0.73 \\
\hline \multirow{13}{*}{2} & \multirow{13}{*}{ Streptococcus } & \multirow{13}{*}{13} & ST1 & $5.22^{\mathrm{a}}$ & $2.62^{b}$ & 0.72 \\
\hline & & & ST2 & $5.24^{\mathrm{a}}$ & $2.00^{\mathrm{b}}$ & 0.32 \\
\hline & & & ST3 & $4.10^{\mathrm{a}}$ & $1.43^{\mathrm{b}}$ & 0.36 \\
\hline & & & ST4 & $3.26^{\mathrm{a}}$ & $1.58^{\mathrm{b}}$ & 0.32 \\
\hline & & & ST5 & $3.26^{\mathrm{a}}$ & $1.14^{\mathrm{b}}$ & 0.35 \\
\hline & & & ST6 & $2.73^{\mathrm{a}}$ & $1.12^{\mathrm{b}}$ & 0.22 \\
\hline & & & ST7 & $3.94^{\mathrm{a}}$ & $3.52^{b}$ & 0.26 \\
\hline & & & ST8 & $3.12^{\mathrm{a}}$ & $1.13^{\mathrm{b}}$ & 0.52 \\
\hline & & & ST9 & $2.97^{\mathrm{a}}$ & $1.16^{\mathrm{b}}$ & 0.21 \\
\hline & & & ST11 & 3.21 & NIL & 0.79 \\
\hline & & & ST12 & $3.08^{\mathrm{a}}$ & $1.13^{b}$ & 0.70 \\
\hline & & & ST14 & $6.18^{\mathrm{a}}$ & $3.39^{b}$ & 0.58 \\
\hline & & & ST15 & $3.76^{\mathrm{a}}$ & $1.13^{\mathrm{b}}$ & 0.21 \\
\hline \multirow{5}{*}{3} & \multirow{5}{*}{ Leuconostoc } & \multirow{5}{*}{5} & LE1 & $3.76^{\mathrm{a}}$ & $1.36^{\mathrm{b}}$ & 0.63 \\
\hline & & & LE2 & $3.10^{\mathrm{a}}$ & $1.10^{\mathrm{b}}$ & 0.67 \\
\hline & & & LE3 & $3.07^{\mathrm{a}}$ & $1.27^{b}$ & 0.32 \\
\hline & & & LE4 & $4.90^{\mathrm{a}}$ & $2.48^{b}$ & 0.36 \\
\hline & & & LE5 & $2.70^{\mathrm{a}}$ & $1.07^{b}$ & 0.42 \\
\hline \multirow{11}{*}{4} & \multirow{11}{*}{ Lactobacillus } & \multirow{11}{*}{11} & LB1 & $4.27^{\mathrm{a}}$ & $1.28^{\mathrm{b}}$ & 0.21 \\
\hline & & & LB2 & $5.63^{\mathrm{a}}$ & $2.86^{\mathrm{b}}$ & 0.05 \\
\hline & & & LB4 & $3.68^{\mathrm{a}}$ & $1.15^{\mathrm{b}}$ & 0.08 \\
\hline & & & LB5 & $4.42^{\mathrm{a}}$ & $1.86^{\mathrm{b}}$ & 0.52 \\
\hline & & & LB8 & $3.09^{\mathrm{a}}$ & $1.19^{\mathrm{b}}$ & 0.04 \\
\hline & & & LB10 & $4.12^{\mathrm{a}}$ & $1.32^{\mathrm{b}}$ & 0.24 \\
\hline & & & LB11 & $3.13^{\mathrm{a}}$ & $1.31^{\mathrm{b}}$ & 0.35 \\
\hline & & & LB21 & $3.52^{\mathrm{a}}$ & $1.23^{\mathrm{b}}$ & 0.43 \\
\hline & & & LB24 & $3.23^{\mathrm{a}}$ & $1.46^{\mathrm{b}}$ & 0.28 \\
\hline & & & LB26 & $2.99^{\mathrm{a}}$ & $1.26^{\mathrm{b}}$ & 0.08 \\
\hline & & & LB28 & 2.92 & NIL & 0.19 \\
\hline
\end{tabular}

Note: Similar superscripts indicate non-significant at the corresponding critical difference

\section{Genotypic identification of acid and bile tolerant lactic isolates}

The parameters related to identification of lactic acid bacterial isolates obtained from dahi samples are presented in Table 3. The table reveals the LAB isolated which are maximum tolerant to both acid as well as bile are further selected for the study purpose. Two lactococcal isolates LL7 and LL10, which were most tolerant to acid and bile, subjected for genotypic identification. Based on these results, LL7 was identified as Lactococcus lactis ssp lactis and LL10 was identified as Lactococcus lactis ssp. lactis bv diacetylactis and their identities were confirmed by $16 \mathrm{~S}$ rRNA sequences. All the five streptococcal isolates ST1, ST2, ST3, ST7 \& ST14, belonged to Streptococcus thermophilus and Leuconostoc isolates, LE1 \& LE4, were identified as Leuconostoc mesenteroids ssp. mesenteroids while the isolates LB2, was identified as Lactobacillus plantarum and isolate LB5, as Lactobacillus fermentum while LB24, was Lactobacillus helveticus. All these isolates confirmed their identity with genotypic 16S rRNA sequencing. Similar study conducted by Rajashekar et al. (2013) have carried out both phenotypic and genotypic identification of 8 acid and bile tolerant lactic isolates obtained from domestic dahi samples of Bengaluru and identity of isolates were confirmed as L.lactis ssp bv diacetylactis (2), S.thermophilus (2), L.mesentroides ssp. mesentroides (2)and L.fermentum (2). 
Table 3: Identification of the lactic acid bacterial isolates obtained from dahi samples

\begin{tabular}{|c|c|c|c|}
\hline SI no & Genus & Isolate code & Isolate identity \\
\hline 1 & \multirow[t]{2}{*}{ Lactococci } & LL7 & L.lactisssp.lactis \\
\hline 2 & & LL10 & 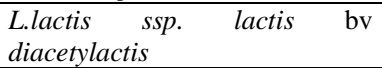 \\
\hline 3 & \multirow[t]{5}{*}{ Streptococcus } & ST1 & \multirow{5}{*}{ Streptococcus thermophilus } \\
\hline 4 & & ST2 & \\
\hline 5 & & ST3 & \\
\hline 6 & & ST7 & \\
\hline 7 & & ST14 & \\
\hline 8 & \multirow[b]{2}{*}{ Leuconostoc } & LE1 & \multirow[t]{2}{*}{$\begin{array}{ll}\text { Leuconostoc } & \text { mesentroides } \\
\text { ssp.mesentroides } & \end{array}$} \\
\hline 9 & & LE4 & \\
\hline 10 & \multirow[b]{3}{*}{ Lactobacillus } & LB2 & L. plantarum \\
\hline 11 & & LB5 & L. fermentum \\
\hline 12 & & LB24 & L. helveticus \\
\hline
\end{tabular}

\section{Conclusion}

The findings for isolation of acid and bile tolerance for LAB after isolation and screening of LAB for dairy products especially Dahi samples which have exhibited wide differences based on the time taken to curdling and DMC counts. The study concludes based on results obtained at various observation, it can be concluded that, the dahi collected from different BBMP zones of Bengalaru showed the presence of lactic acid bacteria and some of the isolates showed better acid and bile tolerance. Apart from causing fermentation of milk, certain lactic cultures also possess health promoting benefits this indicate the probiotic property of the LAB. This study concludes that lactic acid bacteria which is survived under acid and bile posess probiotic nature. Further, these probiotic cultures are identified as genotypes, which can be used as vital inputs for further research use in this line of the study. If these culture used in dahi or other fermented milk product preparation, cosumer will get benefitted by consuming these probiotic products.

\section{Reference}

[1] Bourlioux, p and pochart, p. C. 1998. Nutritional and health properties of yoghurt world rev. Nutr.det. 56:21-58.

[2] Collins, m.d. And gibson, g.r, 1999. Probiotics,prebiotics and symbiotics approaches for modulating the microbial ecology of the gut. Am. J. Clin.nutr.69:1052s-1057s.

[3] El-soda, m., ahmed, n., omran, n., osman, g and morsi, a.,2003. Isolation, identification and selection of lactic acid bacterial culture for cheese making. Emir.j. Food agri 15:51-75.

[4] Food and agriculture organization/world health organization (FAO/WHO), 2001. Report of a joint fao/who expert consultation on evaluation of health and nutritional properties of probiotics in food including powder milk with live lactic acid bacteria, córdoba, argentina,

[5] Mahesh patil, manjunatha, h., sharanagouda, b. And prabha, r. 2016. Occurrence of probiotic lactic isolates in unbranded and branded dahi available in bengaluru market. Frontier j. Vet. Anim. Sci., 5(3):86-89

[6] Miremadi, f., ayush, m., sherkat, f and stojanovrka, 1.2014. Cholesterol reduction mechanism and fatty acid composition of cellular membranes of probiotic lactobacilli and bifidobacteria. J. Funct. Foods.9:295-305.

[7] Mojgani, n., fatimash, h.f., vaseji, n.2015. Characterization of indigenous lactobacillus strains for probiotic properties. Jundishapur j. Microbial 8:1-2.

[8] Oh, y.g and jung, d.s. 2015.evaluation of probiotic properties of lactobacillus and pediococcus strains isolated from omegisool, a traditional fermented millet alcoholic beverage in korea. Lwt food sci.technol.63:437-444.

[9] Rajasekhar, p., prabha, r., ramachandra, b., suchitra, n. And manjunatha, h. 2013. Characterization of lactic acid bacteria obtained from dahi sample of agricultural zones of karnataka. Frontier j. Vet. Anim. Sci., 2(7):131- 134.

[10] Saarela, m., lathenmaki, k., crittenden, r., salminen, s and mattilasandholm t (2002). Gut bacteria and health foods-the european perspective.int.j.food microbial.78:99-117.

[11] Salminen, s., von wright, a., (1998). Current probiotics safety assured, microbial ecol. Health disease 10:68-77.

[12] Stiles, m.e and holzapfel, w. H (1997). Review article :lactic acid bacteria of foods and their current taxonomy. Int. J.food microbial.36:1-29

[13] TANNOCK, G. W., 2004. Identification of Lactobacilli and Bifidobacteria.Current Issues Molec. Biol. 1(1): 53-64 